\title{
Determinants of credit constraint of artisanal fishermen in Ghana
}

\author{
Martinson Ankrah Twumasi ${ }^{1}$ (D) Yuansheng Jiang ${ }^{*}$ Frank Osei Danquah $^{2}$ \\ Abbas Ali Chandio ${ }^{1 D}$ Bright Korankye Asiamah ${ }^{2}$
}

${ }^{1}$ College of Economics, Sichuan Agricultural University (SAU), Chengdu, China. E-mail: yjiang@sicau.edu.cn. "Corresponding author. ${ }^{2}$ College of Management, Sichuan Agricultural University (SAU), Chengdu, China.

\begin{abstract}
Due to the high risk associated with fishing, access to credit becomes very difficult for fishermen. The study was conducted to investigate the determinants of credit constraint on artisanal fishermen with survey data collected from artisanal fishermen in the Western and Central Regions of Ghana. A multi-stage sampling procedure was used to select respondents for the study. Data collected were analyzed with the aid of descriptive and IV-Probit model. Most of the fishermen were in their youthful stage. From the study, while boat ownership and off-fishing activity reduce the probability being credit constrained, complex procedure, and disbursement time lag increase fishermen probability of being credit constrained. The findings of the study also indicated that there is a significant difference between constrained and unconstrained fishermen fishing activity and financial status. Therefore, fishermen in need of additional credit should be catered for to increase their production, hence, livelihood.
\end{abstract}

Key words: Credit constraint, artisanal fishermen, IV-Probit model.

Determinantes da restrição de crédito a pescadores artesanais em Gana

RESUMO: Devido ao alto risco associado à pesca, o acesso ao crédito se torna muito dificil para os pescadores. O estudo foi conduzido para investigar os determinantes da restrição de crédito em pescadores artesanais com dados de pesquisa coletados nas regiões oeste e central de Gana. Um procedimento de amostragem em vários estágios foi usado para selecionar os entrevistados para o estudo. Os dados coletados foram analisados com o auxilio do modelo descritivo e IV-Probit. A maioria dos pescadores estava em sua fase juvenil. A partir do estudo, enquanto a propriedade do barco e a atividade fora da pesca reduzem a probabilidade de restrição de crédito, procedimentos complexos e atraso no desembolso aumentam a probabilidade dos pescadores sofrerem restrição de crédito. Os resultados do estudo também indicaram que há uma diferença significativa entre a atividade pesqueira e a situação financeira dos pescadores com e sem restrição. Portanto, os pescadores que precisam de crédito adicional devem ser atendidos para aumentar sua produção e, portanto, meios de subsistência.

Palavras-chave: restrição de crédito, pescadores artesanais, modelo IV-Probit.

\section{INTRODUCTION}

The engine to accelerate economic growth in less developed countries like Ghana is empowered by investing in prolific activities, especially in the agriculture sector where a large percentage of the population derives their livelihood. This productive investment in the agriculture sector is only attainable if there is much financial backup to sustain the sector. In production, credit is part of the fundamental financial services components that need to be considered when savings becomes difficult due to low income generated by farmers in a developing economy (OMONONA et al., 2010). Ghana's economic growth is primarily based on agriculture. According to the (GHANA STATISTICAL SERVICE., 2018), the agriculture sector contributed $8.4 \%$ to the estimated Gross domestic product (GDP) which recorded a growth rate of $8.5 \%$ in 2017 compared to $3.7 \%$ in 2016 . However, its share of GDP declined from 18.7 percent in 2016 to 18.3 percent in 2017 . The agriculture sector which consists of crops, forestry and logging, livestock, and fishing contributed $14.2 \%, 1.9 \%, 1.1 \%$ and $1.2 \%$ to 2017 GDP respectively. From the potential benefits derived from agriculture, the government of Ghana needs to intensify its financial support for the stakeholders in the agriculture sector to improve production, income, and savings.

Access to credit especially from formal financial institutions (FIs) is widely perceived as an effective strategy to increase smallholder productivity and alleviate poverty (CHANDIO, JIANG, et al., 2018, VISHWANATHA, 2017). Credit accessibility may relax the liquidity constraints that 
artisanal fishermen face and may also increase poor fishermen risk-coping ability; i.e., abolishing less riskier but inefficient strategies to adopt new and risky strategies that lead to high returns in production (SWAMINATHAN et al., 2010). Without the presence of credit, needed inputs for production would be tough to acquire let alone increasing output from available resources (MARTINSON et al., 2019).

However, Ghana has seen a tremendous progression in the financial system through the financial sector reforms. The banking sector is now reasonably competitive, capitalized, sound and solid (BANK OF GHANA, 2007). Despite these developments in the banking sector, the agriculture sector's share of credit received compared to other sectors from the formal FIs is low (ASANTE-ADDO, MOCKSHELL, et al., 2017, ASIEDU-MANTE, 2005). Also, according to ATIENO (2001), formal lenders policies make potential borrowers, particularly poor stakeholders such as fishermen and farmers constrained in their credit demand which in turn affects their production, income, and standard of living.

In a developing country like Ghana, the fishery industry also needs equal attention like other agricultural products such as crops, forestry, and livestock; and therefore, any means of expanding the national production of fish should be of interest. This is because it contributes to the national GDP and domestic demand for fish consumption. In spite of efforts to increase national food production, the country still relies on imports, often in the form of food aid, to maintain adequate supplies. The country's relatively high consumption of fish has meant that food imports have included substantial quantities of fish and fish products (TALL \& FAILLER, 2012).

Artisanal fishermen, especially those in these study areas, are faced with credit constraints due to unavailability of collateral, cumbersome loan application process, high interest rate, delays in disbursement time lag, inadequate savings and other challenging factors demanded by formal financial institution (ACQUAH \& ADDO, 2011; ABUNYUWAH \& BLAY, 2013; OKYERE et al., 2016). Moreover, the conception that high risk is associated with artisanal fishing among lenders could be a contributing factor to their credit constraint status (WEBER \& MUSSHOFF, 2012; TADESSE, 2014). Due to the challenges faced by fishermen in obtaining their desirable credit, fishing inputs become difficult to acquire, therefore, affecting their targeted productivity to enhance their investment (DIANA et al., 2010). An encounter with an official of a rural bank in one of the areas under study revealed that fishermen who had access to credit enjoy economies of scale and can build their savings as well as clearing their loan defaults in time. Again, a retired fisherman also reported that without credit accessibility, his entire fishing career would have been a mess. According to him, credit obtained from formal FIs enabled him to expand his business and also establish an off-fishing income generation activity for his family. Successive governments have not overlooked the potential contribution of the fishery sector to the development of the economy of Ghana but the problem of loss of employment and revenue of fishermen and other ancillary service providers persist due to credit constraints. It is; therefore, necessary to identify the factors influencing fishermen's probability to be credit constrained.

Although, the determinants of credit constraint of smallholder farmers and small and medium enterprises (SMEs) owners in many developing countries have been investigated by a couple of researchers, none if any, addressed the factors influencing artisanal fishermen creditconstraint conditions. Therefore, this study is to fill this gap. This study aimed to examine the determinants of credit constraint of artisanal fishermen in Ghana. The objective of the study is achieved by using survey data collected from Komenda Edina-EguafoAbirem (KEEA) municipal and Secondi-Takoradi (ST) metropolis of the Central and Western Region of Ghana respectively. This study was carried out because there is evidence to show that a large number of poor households are regarded as marginalized in their areas and did not have access to credit because of their weak social and economic conditions. The study also dealt with the problem of endogeneity. Results of the study will help policymakers to identify useful measures which may reduce credit constraint among fishermen and transform fishermen production hence, the agricultural sector through increased access to credit.

This paper is organized as follows. Section 2 provides a literature review of the study. Section 3 provides information on the research methodology. Section 3 presents the results and discussion of the findings; Section 4 provides conclusions and recommendations of the study.

\section{LITERATURE REVIEW}

\section{Theoretical and conceptual framework}

The life-cycle hypothesis ( $\mathrm{LCH})$ model and the permanent income hypothesis (PIH) of ANDO \& MODIGLIANI, (1963) and FRIEDMAN (1957) are viewed as the starting point of the theory 
of household debt and credit constraints. These economists propounded that in a period of low income, households will borrow to finance current consumption and at a point in time where there is high income, households will pay back the credit received. In a world with perfect capital markets, households will be able to borrow the amount of money they desire to smooth their consumption. This means current consumption should be independent of current income. The LCH and PIH do not always hold because at least some consumers face binding credit constraints. Economics theory came out with the view that the tremendous decline in income and welfare may be attributed to the credit constraint, especially those in the poor households because of the massive negative impact of credit constraint on their investment and consumption levels. According to ESWARAN \& KOTWAL, 1990), credit constraint directly causes a fall in household welfare because individuals are restricted to borrow the desired level of credit to smooth consumption in a perilous time. A risk-averse individual, without access to credit, becomes discouraged to participate in risky activities that come with high returns; therefore, causing a reduction in income and welfare.

The independent variables for this study are the demographical factors (age, education level, household size, and marital status), socioeconomic factors (boat ownership, and off-fishing income) and other factors (disbursement time lag, credit access procedure, interest rate, and cooperative member) of the artisanal fishermen. Besides, whether a fisherman is being credit constrained or not constitutes the dependent variable (Figure 1). The role of socioeconomic and demographical factors such as age, education level, household size, marital status, boat ownership, and off-fishing income in determining credit constraint is important to explore because such variables have been identified as factors that influence the probability of a fisherman to be credit constrained in previous studies (ABUNYUWAH \& BLAY, 2013; NYANG 'AYA \& ONYANGO, 2013). It is also important to explore other factors like time lag, credit access procedure, being a cooperative member and interest rate which could also determine access to credit or credit constraint. Understanding the determinants of credit constraint may help identify policies and practices that will encourage fishermen to participate in the credit market to increase their productivity and hence, livelihood only if these funds secured from the credit market are used appropriately.

\section{Existing empirical review}

There exist few previous studies of credit constraint on households. In the cases of inadequate equity funds, a fisherman's ability to secure credit can

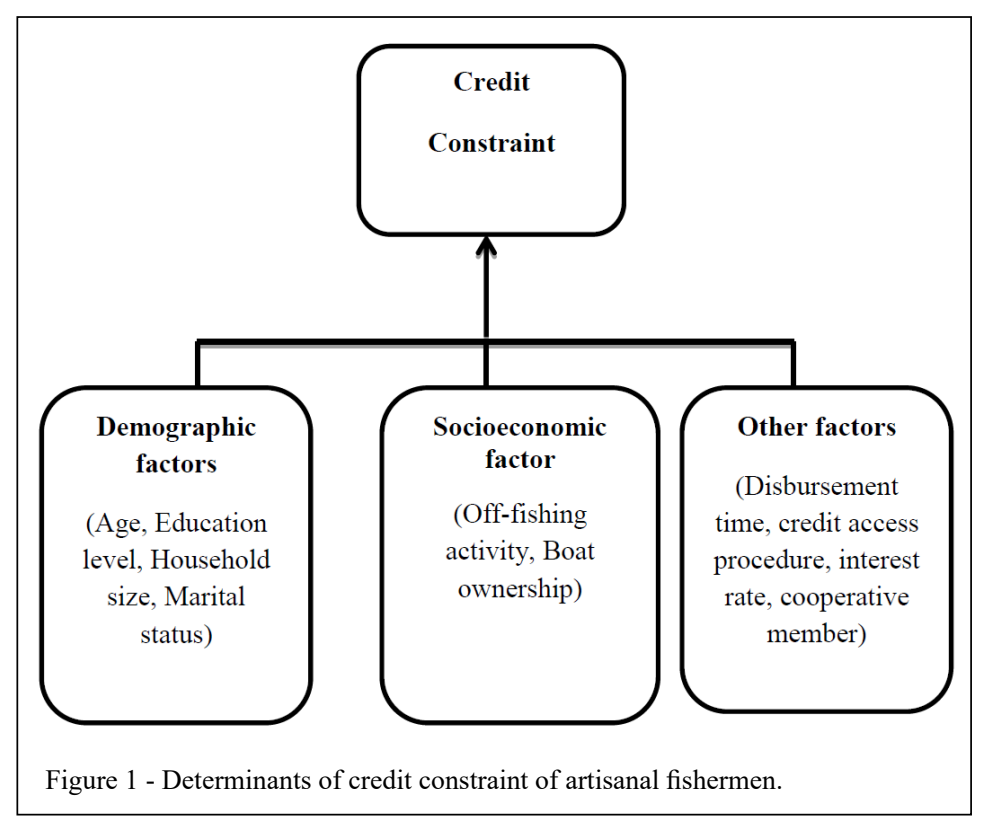

Ciência Rural, v.50, n.3, 2020. 
affect the optimization of output supply by allowing fishermen to use satisfactory levels of inputs for production and also enable the fisherman to make use of new technology. Many variables have been revealed by many researchers as influential factors that lead to credit constraint among artisan fishermen. Few of these factors include lack of collateral and land assets, not being a cooperative member, length of boat and savings level (DONG et al., 2012; NYANG 'AYA \& ONYANGO, 2013; MARTINSON et al., 2019).

Analyzing the determinants of household credit demand and credit constraints in Bosnia and Herzegovina $(\mathrm{BiH})$ was also carried out by $(\mathrm{CHEN} \&$ CHIVAKUL, 2008). They focused on the use of probit model to find the determinant of credit constraint. Their findings showed that age, income, wealth and education qualifications are the main factors driving credit market participation, while high income and high wealth lower credit constraints.

In Ashanti and Brong Ahafo Regions of Ghana, AL-HASSAN (2014) examined credit constraints and how it affects maize production in Ghana. The study utilized the endogenous switching regression approach with survey data collected from 595 maize farmers. The study revealed that credit constraint tremendously affects input use and productivity level of farming. The results showed having an off-farm job, farm size and how operational modalities are perceived as factors that influence credit constraint conditions for farmers.

Also, CHANDIO et al., (2018) investigated the determinants of credit constraints of 180 farm households in Sindh, Pakistan. With the use of probit regression model, frequencies and percentages to analyze the data, the findings of the study concluded that distance to the economic center, cumbersome loan application procedures, high level of interest rate and untimely loan disbursement are the major constraint factors creating hindrances for getting a loan from institutional sources. The study also concluded that higher education attainment and being an owner of an asset such as land reduces the probability of a farmer to be credit constrained.

The role of credit on rice productivity in Central Sulawesi, Indonesia was also investigated by NURYARTONO, (2007). After classifying rice farmers into credit- constrained and creditunconstrained groups using the direct elicitation method, the results of the study obtained using probit and switching regression model showed that the number of years of education, age, wealth and indicators of risk-bearing significantly determines whether a household was credit constrained or not.

The research of OMONONA et al., (2010) examined the factors influencing credit constraint and efficiency of production of farming households in Nigeria, Oyo State. A structured questionnaire was utilized to collect survey data from 120 mixed farmers in the study area. After using descriptive analysis, probit regression and stochastic frontier in analyzing the data, the results showed that 79.2 percent of the respondents were considered credit constrained. The study further revealed that credit constraint negatively affects farmers' production efficiency. The significant variables that influenced the credit constraint conditions of the farmers in the study area were age, gender, education, and dependency ratio of farmers.

\section{METHODOLOGY}

\section{Sample procedure and data collection}

The data included primary measurements collected through a household survey which was conducted between January 2018 and May 2018 in Komenda Edina-Eguafo-Abirem (KEEA) municipal in the central region and Secondi-Takoradi (ST) metropolis in the western region of Ghana. Both regions are considered as major agricultural territories in Ghana, where fishermen and farmers are geographically distributed on both plain and coastal areas and produce various crops and aquatic products. A structured questionnaire was used to elicit relevant respondents' information to identify key householdlevel and other significant factors that influence credit constraint among the artisanal fishermen. Also, the questionnaires gathered both qualitative and quantitative information. The quantitative research utilizes certain measurement techniques while the qualitative research employs observation techniques (BRYMAN, A. \& BELL, 2015).

The multistage sampling technique was employed to solicit for representative households for the study and again, ensure each household had an equal chance of being selected in the sample (ASCIONE, BIANCO, et al., 2016, STAFFORD, REINECKE, et al., 2006). In the first stage, two districts were selected from two regions in Ghana, that is, KEEA from the central region and ST from the western region. The second stage, eight (8) communities were selected, six (6) and two (2) from the KEEA and ST respectively. They included; Aborobeana, Komenda, Ampenyi, Bamtoma, Elmina and Ankaful for KEEA and New Amaful and New Takoradi for ST. These communities were selected 
because they are along the coastal stretch of the two areas of study (KEEA and ST) and fishing is the main industry in those areas. The final stage also involved simple random sampling to locate respondents (artisanal fishermen). Some opinion leaders and fishermen cooperative association leaders of the various communities assisted us in our data collection. Fifty (50) respondents were selected from each community randomly; therefore, in all a total of 400 fishermen were sampled for the study. The regression model was tested for multi-collinearity using a variance inflation factor (VIF). The results showed that the mean VIF was below 10, i.e., 2.87, implying that there exist no serious multi-collinearity problem between the explanatory variables used in the model (CHATTERJEE \& HADI, 2006).

\section{Empirical model}

The empirical approach used by many researchers to analyze credit constraints from the perspective of rural households is the binary logit and probit model. Both logit and probit models provided consistent, efficient, and asymptotically normal estimates, and yield very similar prediction results in empirical research. However, this paper utilized the observed information of respondent's (constraint or unconstraint) and respondent's characteristics to estimate their probability of being credit constraint or not on the household characteristics using the Probit model because of its good approximation to the normal distribution and analytical convenience (BEN-AKIVA \& LERMAN, 1985; WOOLDRIDGE, 2013). Additionally, to solve the endogenous problem of the credit constraint of the fishermen, we employed the IV-Probit developed by NEWEY, (1987). In this study, the dependent variable is whether a fisherman is being credit constrained, that is, 1 for fisherman who complained of being credit constrained and 0 otherwise. A credit constraint status of a fisherman is a function of demographical factors (age, education level, household size and marital status), socioeconomic factors (boat ownership and off-fishing income) and other factors (disbursement time lag, credit access procedure, interest rate and cooperative member).

There may be a causal relationship between off-fishing income and the credit constraint status. Thus, off-fishing activities may affect the credit constraint status of the fisherman and the fishermen's credit constraint status may also affect off-fishing income. For example, a credit-constrained fisherman may be limited in resources to invest in any off-fishing venture. In the same way, investing in an off-fishing venture may increase the total household income of the fisherman and therefore, less likely to be credit constrained. Therefore, the off-fishing income of the fisherman is treated as endogenous. Since finding a suitable instrument for instrumental variable analysis is a big challenge, we followed previous studies approach (ZHAO, 2003; PFEIFFER et al., 2009) to use social network (whether a relative can help introduce off-fishing job) as an instrument for the off-fishing income variable in equation 1 . For instance, a fisherman's relative with a job opportunity is more likely to give the job to someone of the same household. This means that social networks may not influence the credit constraint status directly but only through the off-fishing income variable. The IVProbit model for this study can be expressed as:

$$
\begin{aligned}
\mathrm{Y}^{*} & =\beta_{\mathrm{n}}+\beta_{1} \text { off }- \text { fishingincome }+\gamma \mathrm{X}+\mu_{\mathrm{i}} \\
\mathbf{Y}_{\mathrm{i}} & = \begin{cases}\mathbf{1} \text { if, } & \mathrm{Y}_{\mathrm{i}}^{*}>\mathbf{0} \\
0 \text { if, } & \text { otherwise }\end{cases}
\end{aligned}
$$

Among them, $\mathrm{Y}_{\mathrm{i}}$ is a dummy variable in which a value of 1 represent that the fisherman was credit-constrained and 0 represents otherwise; offfishingincome is the focal variable for the model; $\mathrm{X}$ represents vector of control variables; $\beta_{0}$ is a constant; $\gamma$ and $\beta^{1}$ are the estimated parameters for the focal variable and other control variables respectively; $\mu_{\mathrm{i}}$ represents the error term of the model.

The basic model is estimated as:

$\mathrm{Y}_{\mathrm{i}}=\varnothing_{0}+\varnothing_{1} \mathrm{X}_{1}+\varnothing_{2} \mathrm{X}_{2}+\varnothing_{3} \mathrm{X}_{3}+\varnothing_{4} \mathrm{X}_{4}+\varnothing_{5} \mathrm{X}_{5}+\varnothing_{6} \mathrm{X}_{6}$ $+\varnothing_{7} X_{7}+\varnothing_{8} X_{8}+\varnothing_{9} X_{9}+\beta_{10} X_{10}+\beta_{11} X_{11}+\varepsilon_{i}$ where the meaning of $Y_{i}$ is similar to that in equation 1. $X_{1}$ represents off-fishing income, $X_{2}$ represents education, $\mathrm{X}_{3}$ represents procedure, $\mathrm{X}_{4}$ represents marital status, $X_{5}$ represents cooperative member, $X_{6}$ represents boat ownership, $X_{7}$ represents household size, $X_{8}$ represents disbursement time lag, $\mathrm{X}_{9}$ represents age, and $\mathrm{X}_{10}$ represents age square, $X_{11}$ represents interest rate (Table 1 for detail description), $\varnothing_{1}, \varnothing_{2}, \varnothing_{3}, \varnothing_{4}, \varnothing_{5}, \varnothing_{6}, \varnothing_{7}, \varnothing_{8}, \varnothing_{9}, \varnothing_{10}, \varnothing_{11}$ are the parameters of the model to be estimated and $\varepsilon_{\mathrm{i}}$ represents random disturbance term.

\section{RESULTS AND DISCUSSIONS}

Descriptive statistics of socioeconomic and other characteristics of the respondents

Loan rejection or rationing is not the only measurement of being credit constrained, but the inability of an individual to handle risk and their perceptions of the transaction cost (risks-rationing) are also a cause of it (DIANA et al., 2010). Thus, the decision to refuse to apply for credit though it is needed and the decision made by lenders' to reject 
Table 1 - Socioeconomic, Demographic and other characteristics of the respondents.

\begin{tabular}{|c|c|c|c|}
\hline Variables & Description & Mean & Std. Dev. \\
\hline $\begin{array}{l}\text { Dependent Variable } \\
\text { Credit constraint }\end{array}$ & 1 if the respondent is credit constrained and 0 otherwise & 0.62 & 0.46 \\
\hline $\begin{array}{l}\text { Independent variables } \\
\text { Focal variable } \\
\text { Off-fishing income }\end{array}$ & Respondents off-fishing income in cedis $(\mathrm{GH} \phi)$ & 960.99 & 662.29 \\
\hline Education & 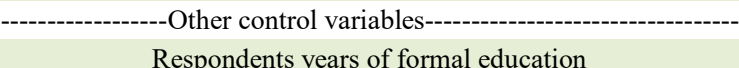 & 4.90 & 4.51 \\
\hline Procedure & 1 if procedure for acquiring loan is complex and 0 otherwise & 0.37 & 0.49 \\
\hline Marital status & 1 if the respondent is married and 0 otherwise & 0.47 & 0.50 \\
\hline Cooperative member & 1 if the respondent is a member of a cooperative and 0 otherwise & 0.34 & 0.47 \\
\hline Boat ownership & 1 if the respondent owns a boat and 0 otherwise & 0.39 & 0.49 \\
\hline Household size & Total number of household size & 3.49 & 1.13 \\
\hline Disbursement time lag & Time lag in loan disbursement in months & 2.33 & 1.22 \\
\hline Age & Respondents age & 29.19 & 7.72 \\
\hline Interest rate & Interest rate on loans in $\%$ & 23.84 & 1.54 \\
\hline Income & Respondents monthly income in cedis $(\mathrm{GH} \phi)$ & 942.90 & 702.06 \\
\hline Savings & Total amount of respondent saving in cedis $(\mathrm{GH} \phi)$ & 928.44 & 460 \\
\hline Off-fishing activity & $\begin{array}{l}1 \text { if the respondent has off-fishing income-generating activities } \\
\text { and } 0 \text { otherwise }\end{array}$ & 0.66 & 0.47 \\
\hline Social Network & 1 if the respondent relative can help introduce off-fishing job & 0.20 & 0.40 \\
\hline
\end{tabular}

Source: survey results, 2018.

credit application or allocate an undesirable amount less than what loan applicants demanded are the two main activities classified as credit constraint in this study. Conversely, applicants who received the total amount of credit demanded and non-applicants who refused to borrow due to excess liquidity were classified as being credit-unconstrained. In this present study, the entire 400 fishermen reported that the presence of credit is essential to support their production and consumption activities but only $341(85.25 \%)$ applied for credit. Among the applicants, $132(38.71 \%)$ were credit constrained and $209(61.29 \%)$ were unconstrained. Among the non-applicants, $21 \quad(35.60 \%)$ were credit constrained based on risk-rationing while 38 $(64.40 \%)$ were classified as credit unconstraint because they did not need credit support. In all 153 $(38.25 \%)$ fishermen were classified as being creditconstrained while $247(61.75 \%)$ fishermen were not credit-constrained.

Socioeconomic and other characteristics of the respondents in the study area are displayed in table 1 . The results in the table revealed that the means of the respondents' savings, income, household size, disbursement lag, age, interest rate, education level, off fishing income and being credit constrained were $928.44 \pm 460,942.90 \pm 702.06$, $3.49 \pm 1.13,2.33 \pm 1.22,29.19 \pm 7.72,23.84 \pm$ $1.54,4.90 \pm 4.51,960.99 \pm 662.29$ and $0.62 \pm 0.46$ respectively. This result implies that the majority of the fishermen in the study area are dominated by youths endowed with adequate energy to tackle the challenges of fish production but their level of formal education was very low. An individual's low level of education affects being credit constrained positively (UGWUMBA \& OMOJOLA, 2013).

The results further revealed that $66 \%$ of the respondents have off-fishing income-generating activities. The high proportion of those with offfishing income activities might be due to the low income generated from fishing and the high level of their household consumption. Again, 47\% were married. Respondents who were members of a cooperative were only $34 \%$. Most of the respondents were not cooperative members because of the payment of membership dues. Again, about 37\% of the fishermen agreed that the procedure for acquiring loan is complex and $39 \%$ of the respondents were boat owners. Fishermen who have their boat were few because the cost of a boat in the study area is expensive to acquire and only the well to do fishermen could afford it. 
Difference between means of fishing activity inputs and financial status of respondents

Moreover, the researchers of this study carried out a test to investigate whether there are significant average differences between constrained and unconstrained fishermen's fishing activities inputs and financial status in the study area. From table 2, the average total amount of savings and monthly income were $\mathrm{GH} \not 805.303$ and $\mathrm{GH} \not 839.736$ for credit-constrained fishermen respectively while $\mathrm{GH} \notin 1006.22$ and $\mathrm{GH} \notin 1008.059$ for creditunconstrained fishermen respectively. The differences were also statistically significant. This is because constrained fishermen do not save due to the low level of income generated. They can only save from their income and since income is low due to inadequate funds to increase their productions, savings are also affected. Also, the differences between the average number of crews per trip and expenditure on fuel per month for credit constrained and unconstrained fishermen are statistically significant. Precisely, an average of 11 and 10 crews per trip for credit unconstrained and constrained fishermen respectively while credit constrained and unconstrained fishermen recorded $\mathrm{GH} \phi 40$ and $\mathrm{GH} \phi 46$ average monthly fuel expenditure respectively. This result agreed with OKYERE et al., (2016) who reported that credit access improves the production of artisanal fishermen.

\section{Determinants of artisanal fishermen credit constraints}

Table 3 presents the results of the IVProbit regression analysis used to identify factors influencing farmers being credit constrained or not including the marginal effects. The IV-Probit model had a log-likelihood value of -2657.8243 . The entire models were significant at $1 \%$. It is evident from table 3 that savings, procedure, boat ownership, and disbursement time lag were the variables that significantly influence the credit constraint conditions of the fishermen under study. The remaining variables are not significant.

Fishermen off-fishing income was reported to be significant at $1 \%$ and also had a negative coefficient with a marginal effect of 0.145 . This implies that a GH $\not 1$ increase in off-fishing income reduces the probability of a fisherman to be credit-constrained. Fishermen who engaged in off-fishing activities are less likely to be credit constrained compared to their counterparts who are not a participant of off-fishing activities. This is because fishermen engaged in off-farm activities consumption and investment activities are supported by the extra income generated from the off- fishing activities. Also, FIs see those with extra income generating activities as creditworthy; and therefore, FIs are more likely to lend them credit. This finding was consistent with the findings of SEBATTA et al., (2014) and AL-HASSAN (2014) who concluded that off-farm income increases farmers' chance to secure formal credit.

The procedure in securing a loan was positively significant at $5 \%$. This result implied that as procedure for securing a loan becomes more cumbersome, the probability of being credit constrained increases. This is because a complex procedure limits the uneducated fishermen to acquire a loan; therefore, being credit constrained. Again, respondents feel it troublesome dealing with complex

Table 2 - Difference between means of fishing activity input and financial status of credit constraint and unconstrained fishermen.

\begin{tabular}{|c|c|c|c|c|}
\hline Variables & Total & Constraint & Unconstraint & p-value \\
\hline Number of trips per month & $\begin{array}{c}6.551 \\
(1.789)\end{array}$ & $\begin{array}{c}6.477 \\
(1.888)\end{array}$ & $\begin{array}{c}6.598 \\
(1.727)\end{array}$ & 0.5444 \\
\hline Number of crew per trip & $\begin{array}{l}11.229 \\
(2.454)\end{array}$ & $\begin{array}{l}10.909 \\
(2.330)\end{array}$ & $\begin{array}{l}11.431 \\
(2.515)\end{array}$ & $0.0559^{*}$ \\
\hline Trip fuel expenditure per month & $\begin{array}{c}43.716 \\
(17.267)\end{array}$ & $\begin{array}{c}39.977 \\
(15.591)\end{array}$ & $\begin{array}{c}46.077 \\
(17.883)\end{array}$ & $0.0014^{* * *}$ \\
\hline Fishermen total amount of savings & $\begin{array}{c}928.446 \\
(460)\end{array}$ & $\begin{array}{c}805.303 \\
(407.012)\end{array}$ & $\begin{array}{c}1006.22 \\
(475.237)\end{array}$ & $0.0001^{* * *}$ \\
\hline Fishermen monthly income & $\begin{array}{c}942.901 \\
(702.065)\end{array}$ & $\begin{array}{c}839.736 \\
(673.094)\end{array}$ & $\begin{array}{l}1008.059 \\
(713.677)\end{array}$ & $0.0308^{* *}$ \\
\hline
\end{tabular}

Source: survey results, 2018. Asterisks ${ }^{*},{ }^{* *}$ and ${ }^{* * *}$ represent significant levels at $10 \%, 5 \%$ and $1 \%$ respectively. Standard errors in parentheses. 
Table 3 - Results of IV-Probit regression and marginal effect analysis on the factors influencing the credit constraint conditions of fishermen.

\begin{tabular}{|lccc}
\hline Variables & Coefficient & Robust Std. Err & Marginal effect \\
\hline Off fishing Income & $-0.0012233^{* * *}$ & 0.0002631 & -0.0004547 \\
\hline Education & -0.028899 & 0.0230106 & -0.0107417 \\
\hline Procedure & $0.4343961^{* *}$ & 0.2154056 & 0.1631174 \\
\hline Marital status & -0.1008658 & 0.1703785 & -0.0374469 \\
\hline Cooperative member & -0.2737482 & 0.1707191 & -0.0999563 \\
\hline Boat ownership & $-0.457736^{* *}$ & 0.1920132 & -0.1657706 \\
\hline Household size & 0.0265105 & 0.0722838 & 0.0098539 \\
\hline Disbursement time lag & $0.546087^{* * *}$ & 0.2013171 & 0.2029797 \\
\hline Age & -0.0192087 & 0.0444928 & -0.0071398 \\
\hline Age & 0.0002306 & 0.0006229 & 0.0000857 \\
\hline Interest rate & -0.0286492 & 0.0510972 & -0.0106489 \\
\hline Constant & 0.7755145 & 1.642544 & - \\
\hline
\end{tabular}

Log pseudolikelihood $=-2657.8243$

Wald $X^{2}=200.54$

Wald test of exogeneity $(/$ athrho $=0): \operatorname{chi}^{2}(1)=5.55$ Prob $>$ chi $^{2}=0.0185$ Source: survey results, 2018. Asterisks ${ }^{* *}$ and ${ }^{* * *}$ represent significant levels at $5 \%$ and $1 \%$ respectively.

issues. This finding was consistent with (UGWUMBA \& OMOJOLA, 2013; CHANDIO et al., 2018) findings. They reported that a complex credit lending procedure affects the less educated access to credit.

Boat ownership inversely affects credit constraint status and it was found to be $5 \%$ significant. This implied that more proportion of boat ownership will decrease the probability of a fisherman being constrained. A fisherman's ability to own a boat indicates the creditworthy of that fisherman; and therefore, lenders are more likely to offer them their loan application offer. Alternatively, fishermen who own a boat may earn higher revenue through renting out their boats and may not need credit, leaving them credit unconstrained. This result agreed with the findings of AL JABRI et al., (2013) and OKYERE et al., (2016).

The disbursement time lag of loan application was found significant and has a positive coefficient. This result means that when disbursement time lag of loan application increases by a month, the probability of a fisherman being credit constrained also increased. The reason is that, loans are needed for a specific task at a specific time and therefore the essence of acquiring a credit becomes insignificant if the time lag of loan disbursement delays, leading to credit constraint. This is similar to the findings of CHANDIO et al. (2018).

\section{CONCLUSION}

The study was conducted to estimate the determinants of credit constraint on artisanal fishermen in the study area. A multi-stage sampling procedure was used to select respondents for the study. Data collected were analyzed with the aid of the descriptive and probit model. Most of the fishermen were in their youthful stage. While boat ownership and off-fishing income reduce being credit constrained, complex procedure, and disbursement time lag increase fishermen probability of being credit constrained. The findings of the study also indicated that there is a significant difference between constrained and unconstrained fishermen fishing activity inputs and financial status.

To curtail some of these challenges faced by fishermen being credit constrained, measures such as the introduction of concessionary interest rates; removal of cumbersome loan processing procedures; and the reduction of the time lag of loan disbursement must be highlighted through the formulation of policies. There will be assurance of credit availability and accessibility should those measures mentioned be implemented. This will not only improve fishermen productivity but also their welfare as a whole.

\section{ACKNOWLEDGEMENT}

We gratefully acknowledge the financial supports from the Soft Science Program of Sichuan Department of Sci-

Ciência Rural, v.50, n.3, 2020. 
technology (Grant No. 18RKX0773) and Sichuan Agriculture University, College of Economics. The authors also extend great gratitude to the anonymous reviewers, editors and the chief editors of the journal for their helpful review and critical comments.

\section{DECLARATION OF CONFLICT OF INTERESTS}

The authors declare no conflict of interest. The founding sponsors had no role in the design of the study; in the collection, analyses, or interpretation of data; in the writing of the manuscript; and in the decision to publish the results.

\section{AUTHORS' CONTRIBUTIONS}

All authors contributed equally for the conception and writing of the manuscript. All authors critically revised the manuscript and approved of the final version.

\section{REFERENCES}

ABUNYUWAH, I., BLAY, J. K. "Accessibility constraints of small-scale fish farmers to formal in the Nzema East Municipality", Journal of Economics and Sustainable Development, v.4, n.1, p.128-133, 2013.

ACQUAH, H. D., ADDO, J. "Determinants of Loan Repayment Performance of Fishermen Determinants of Loan Repayment Performance of Fishermen: Empirical Evidence From Ghana", Cercetări Agronomice în Moldova, v.XLIV, n.4 (148), p. 89-97, 2011.

AL-HASSAN, R. M. "Credit constraints and smallholder maize production in Ghana", International Journal of Agricultural Resources, Governance and Ecology, v.10, n.3, p.239-256, 2014. doi: 10.1504/IJARGE.2014.064007.

AL JABRI, O., COLLINS, R., SUN, X., et al. "Determinants of Small-scale Fishermen's Income on Oman's Batinah Coast", Marine Fisheries Review, v.75, n.3, p.21-32, 2013. DOI: 10.7755/MFR.75.3.3. Available from: <http://spo.nmfs.noaa.gov/ $\mathrm{mfr} 753 / \mathrm{mfr} 7533 . \mathrm{pdf}>$.

ANDO, A., MODIGLIANI, F. "The "Life Cycle" Hypothesis of Saving: Aggregate Implications and Tests", The American Economic Review, 1963. doi: 10.1126/science.151.3712.867-a.

ASANTE-ADDO, C., MOCKSHELL, J., ZELLER, M., et al. "Agricultural credit provision: what really determines farmers' participation and credit rationing?", Agricultural Finance Review, v.77, n.2, p.239-256, 2017. doi: 10.1108/AFR-02-20160010 .

ASCIONE, F., BIANCO, N., DE STASIO, C., et al. "Multistage and multi-objective optimization for energy retrofitting a developed hospital reference building: A new approach to assess cost-optimality", Applied Energy, 2016. doi: 10.1016/j. apenergy.2016.04.078.

ASIEDU-MANTE, E. “'Integrating financial services into poverty reduction strategies: institutional experience in Ghana', paper presented at the Regional workshop on Integrating Financial Services into Poverty Reduction Strategies, 13-15, September, Abuja, Nigeria.”, 2005.
ATIENO, R. "Formal and Informal Institutions' Lending Policies and Access to Credit by Small Scale Enterprises in Kenya: An Empirical Assessment, AERC Research Paper 111”, 2001.

BANK OF GHANA. "A Note on Microfinance in Ghana, Working Paper, Research Department, Accra, Ghana.”, 2007.

BEN-AKIVA, M., LERMAN, S. R. Discrete Choice Analysis. Theory and Application to Travel Demand. [S.l: s.n.], 1985.

BRYMAN, A. \& BELL, E. Business Research Methods - Alan Bryman, Emma Bell - Google Books. [S.1: s.n.], 2015.

CHANDIO, A. A., JIANG, Y., WEI, F., et al. "Effects of agricultural credit on wheat productivity of small farms in Sindh, Pakistan: Are short-term loans better?", Agricultural Finance Review, 2018. doi: 10.1108/AFR-02-2017-0010.

CHATTERJEE, S., HADI, A., "Introduction To Linear Regression 1.1". Regression Analysis by Example, [S.1: s.n.], 2006. . DOI: 10.1198/tech.2007.s499.

CHEN, K. C., CHIVAKUL, M. "What Drives Household Borrowing and Credit Constraints? Evidence From Bosnia and Herzegovina", IMF Working Papers, v.08, n.202, p.1, 2008. DOI: $10.5089 / 9781451870602.001$. Available from: <http:// elibrary.imf.org/view/IMF001/09458-9781451870602/094589781451870602/09458-9781451870602.xml>.

DIANA, F., GUIRKINGER, C., BOUCHER, S. "Risk, credit constraints and financial efficiency in Peruvian agriculture", Journal of Development Studies, 2010. doi: $10.1080 / 00220380903104974$.

DONG, F., LU, J., FEATHERSTONE, A. M. "Effects of credit constraints on household productivity in rural China", Agricultural Finance Review, v.72, n.3, p.402-415, 2012. DOI: 10.1108/00021461211277259.

ESWARAN, M., KOTWAL, A. "Implications of credit constraints for risk behaviour in less developed economies", Oxford Economic Papers, 1990. doi: 10.1093/oxfordjournals.oep.a041958.

FRIEDMAN, M. "Introduction to" A Theory of the Consumption Function"', A Theory of the Consumption Function, 1957. DOI: $10.2307 / 1926352$.

GHANA STATISTICAL SERVICE. "Statistics for Development and Progress Provisional 2017 Annual Gross Domestic Product", n. April, 2018. Available from: <www.statsghana.gov.gh>.

MARTINSON, A. T., YUANSHENG, J., MONICA, O. A. "Determinants of agriculture participation among tertiary institution youths in Ghana", Journal of Agricultural Extension and Rural Development, v.11, n.3, p.56-66, 2019. doi: 10.5897/ jaerd2018.1011.

NEWEY, W. K. "Efficient estimation of limited dependent variable models with endogenous explanatory variables", Journal of Econometrics, 1987. doi: 10.1016/0304-4076(87)90001-7.

NURYARTONO, N. "CREDIT RATIONING OF FARM HOUSEHOLDS AND AGRICULTURAL PRODUCTION: EMPIRICAL EVIDENCE IN THE RURAL AREAS OF CENTRAL SULAWESI, INDONESIA”, Jurnal Manajemen \& Agribisnis, 2007. doi: 10.17358/JMA.4.1.15-21.

Ciência Rural, v.50, n.3, 2020. 
NYANG 'AYA, R. O. A., ONYANGO, O. J. "Accessing Credit Finance by Artisanal Fishermen: The Case of Lake Victoria in Kisumu, Kenya”, International Journal of Science and Research (IJSR) ISSN (Online Index Copernicus Value Impact Factor, v.14,n.5,p.2319-7064,2013. doi: 10.1080/00031305.2012.708641. Available from: <www.ijsr.net>.

OKYERE, D. O., COLEMAN, M., AMOATENG, E. "Contribution of Microcredit to Artisanal Fishing in Sekondi-Takoradi Metropolis Western Region of Ghana", Journal of Social Science Studies, v.3, n.2, p.205, 2016. doi: 10.5296/jsss.v3i2.9275. Available from: $<$ http:// www.macrothink.org/journal/index.php/jsss/article/view/9275>.

OMONONA, B. T., LAWAL, J. O., OYINLANA, A. O. "Determinants of credit constraint conditions and production efficiency among farming households in Southwestern Nigeria", Social Sciences, v.5, n.4, p.326-331, 2010.doi: 10.3923/ sscience.2010.326.331.

PFEIFFER, L., LÓPEZ-FELDMAN, A., TAYLOR, J. E. "Is off-farm income reforming the farm? Evidence from Mexico", Agricultural Economics, 2009. doi: 10.1111/j.15740862.2009.00365.x.

SEBATTA, C., WAMULUME, M., MWANSAKILWA, C. "Determinants of Smallholder Farmers' Access to Agricultural Finance in Zambia", Journal of Agricultural Science, v.6, n.11, p.63-73, 2014. doi: 10.5539/jas.v6n11p63. Available from: <http:// www.ccsenet.org/journal/index.php/jas/article/view/37899>.

STAFFORD, J. D., REINECKE, K. J., KAMINSKI, R. M., et al. "Multi-stage sampling for large scale natural resources surveys:
A case study of rice and waterfowl", Journal of Environmental Management, 2006. DOI: 10.1016/j.jenvman.2005.04.029.

SWAMINATHAN, H., SALCEDO DU BOIS, R., FINDEIS, J. L. "Impact of Access to Credit on Labor Allocation Patterns in Malawi", World Development, 2010. doi: 10.1016/j. worlddev.2009.11.002.

TADESSE, M. "Fertilizer adoption, credit access, and safety nets in rural Ethiopia", Agricultural Finance Review, 2014. doi: 10.1108/AFR-09-2012-0049.

TALL, A., FAILLER, P. "Fishery and aquaculture industry in Ghana", Series Report of the Review of the Fishery and Aquaculture Industry in the 22 ATLAFCO Member States, n. October 2012, p.44, 2012. doi: 10.13140/RG.2.1.1624.3362.

UGWUMBA, C. O. A., OMOJOLA, J. T. "Credit access and productivity growth among subsistence food crop farmers in Ikole local Government Area of Ekiti State, Nigeria", Journal of Agricultural and Biological Science. ISSN 1990-6145, 2013.

VISHWANATHA, M. E. "Access to Microcredit for Smallholder Agricultural Producers in Rwanda (Africa) : Emerging Challenges and Issues", Journal of Commerce \& Management Thought, 2017. doi: 10.5958/0976-478X.2017.00027.1.

WEBER, R., MUSSHOFF, O. "Is agricultural microcredit really more risky? Evidence from Tanzania", Agricultural Finance Review, 2012. doi: 10.1108/00021461211277268.

WOOLDRIDGE, J. M. Introductory Econometrics. 2013 [S.l: s.n.], 2013.

ZHAO, Y. The role of migrant networks in labor migration: The case of China. Contemporary Economic Policy. [S.1: s.n.]., 2003. 